The $5^{\text {th }}$ International Conference on Family Business and Entrepreneurship

\title{
ONLINE TAX PROCESSES IMPLEMENTATION AND CAPABILITY OF SELECTED TAXPAYERS IN MANDURIAO, ILOILO CITY
}

\author{
Marivic G. Villanueva ${ }^{1}$, Rowena Cristina D. Dela Cruz ${ }^{2}$ \\ ${ }^{1,2}$ Faculty of Business, Colegio de la Purisima Concepcion, Corresponding author: sgs@purisima.edu.ph
}

\begin{abstract}
Majority of the population has limited knowledge on taxation and filing of taxes over the counter much more on online filing. The study aimed to determine the level of online tax processes implementation of BIR Iloilo City and the degree of online tax processes capability of selected taxpayers in Manduriao, Iloilo City from November to December 2020. The descriptive-correlational research design and Technology Acceptance Model (TAM was used as support of the study. The model shows haw users come to accept and use the technology. Descriptive and inferential statistics were also used. A researchermade questionnaire was distributed to randomly select 155 taxpayers in Manduriao, Iloilo City. Data were analyzed and interpreted using the Statistical Package for Social Science Software (SPSS) applying frequency count, percentage, mean. T-test, f-test, analysis of variance and Pearson $r$ were availed to test variances and similarities. Findings highlighted that the BIR level of online tax processes implementation was high as to perceived credibility and ease of use. The degree of online tax processes capability was high particularly in technical knowledge. There was a significant difference in the level of online tax processes implementation considering highest educational attainment while variation was not evident as to sex, age, business industry and years in business. The level of online tax processes implementation of BIR Iloilo City correlated with the degree of online tax processes capability of selected taxpayers in Manduriao, Iloilo City.
\end{abstract}

Keywords: Tax process, Implementation, Tax payers, Capability

\section{Introduction}

Globally, the tax environment is changing rapidly. The government of Albania and China, are under an increasing pressure to improve the delivery of public services in - ways. The Bureau of Internal Revenue (BIR) launched an alternative ePayment channel such as GCash, PayMaya, LBP, DBP, and Union Bank ATM/BancNet which will allow taxpayers to settle their taxes online. Electronic filing has been extended to other countries. In almost every country, the government derives a majority of its revenues for financing public goods and services from taxation. Taxpayer need a convenient manner of filing and payment of tax liabilities in the Philippines, the Bureau of Internal Revenue (BIR) prescribed the use of Electronic Filing and Payment System (eFPS) and Electronic Bureau of Internal Revenue Forms (eBIRForms) that provides taxpayers paperless tax filing experience and can also pay their taxes online (BIR, 2013).

Electronic tax filing or e-filing is a process where tax documents or tax returns are submitted through the internet, usually without the need to submit any paper return. Electronic tax filing or e-filing is a process where tax documents or tax returns are submitted through the internet, usually without the need to submit any paper return. Electronic tax filing was first coined in the United States, where the Internal Revenue Services (IRS) began offering tax return e-filing for tax refunds only (Muita, 2011). Electronic tax filing was first coined in the United States, where the Internal Revenue Services (IRS) began offering tax return e-filing for tax refunds only (Muita, 2011).

In order to meet the challenge, tax authorities are turning to e-government led solutions like electronic tax 
filing (e-filing). There is a need to understand the acceptance of the users of the electronic tax-filing and payment systems and identify the factors that can affect their decision to use or not use these online tax facilities. Both systems are to facilitate taxpayers to fulfil their tax obligations hassle-free thus encouraging tax compliance and accordingly increase the tax collection amount that can be used to provide better facilities for the public. Electronic filing is the modern way of tax authorities interacting with tax payers. However, awareness and tax knowledge are some factors that affect taxpayers in carrying out its tax obligation. The additional electronic payment platform provides another convenient way for taxpayers to pay taxes and improve tax compliance and client satisfaction (BIR, 2020). Despite all the efforts aimed at developing a better and easier tax online payment facility, such remained unnoticed or were underused by the public. According to Taylor (2003) Government's use of information technologies in their services to the citizen will lead to better deliveries of the government services, more efficient management, less corruption, more transparency, greater convenience, increased revenue and reduced costs. This has grown to the level that currently approximately one out of every five individual taxpayers is filing electronically.

\section{Statement of the Problem}

The study was conducted to determine the level of online tax processes implementation and determine the degree of online tax processes capability of selected taxpayers in Mandurriao, Iloilo City during the school year 2020-2021. Specifically, the study aims to find answers to the following questions:

1. What is the level of online tax processes implementation of selected taxpayers as a whole and in terms of usefulness, ease of use and perceived credibility?

2. What is the degree of online tax processes capability of selected taxpayers as a whole and in terms of awareness and technical knowledge?

3. Is there a significant differences in the level of online tax processes implementation in terms of usefulness, ease of use and perceived credibility as perceived among respondents when grouped according to sex, age, highest educational attainment, business industry and years in business?

4. Is there a significant differences in the degree of online tax processes capability of the selected taxpayers in terms of awareness and technical knowledge when grouped according to sex, age, highest educational attainment, business industry and years in business?

5. Is there a significant relationship between the level of online tax processes implementation and the degree of online tax processes capability of selected taxpayers in Mandurriao, Iloilo City?

\section{Hypotheses of the Study}

Based on the aforementioned problems, the following hypotheses were derived:

1. There is no significant difference in the level of online tax processes implementation as perceived among respondents when grouped according to sex, age, highest educational attainment, business industry and years in business.

2. There is no significant difference in the degree of online tax processes capability of selected taxpayers when grouped according to sex, age, highest educational attainment, business industry and years in business.

3. There is no significant relationship between the level of online tax processes implementation and the degree of online tax processes capability of selected taxpayers in Mandurriao, Iloilo City.

\section{Theoretical Framework}

This study was anchored on the information systems theory of Davis (1989) entitled Technology Acceptance Model (TAM). Davis, TAM is an information systems theory that models how users come to accept and use a technology. TAM is an adaptation of Theory of Reasoned Action (TRA) and specifically tailored for modelling user acceptance of information systems (Chung, 2008). The model proposes that when users are presented with a particular technology, two particular beliefs namely perceived ease of use and perceived usefulness affect their behavioral intention to use the system which is defined as the extent of users' confidence in the Internet tax-filing system's ability to protect the user's personal information and security. Another determinant that has a significant impact on behavior intention is perceived credibility of a computer system developed by Wang (2002) and Chang et al. A credible website needs to safeguard personal information from unauthorized access or disclosure, accidental loss and alteration or destruction (Chang et al, 2005). Introduced in 1989 by Fred D. Perceived ease of use refers to the extent to which a user believes that using a new information system demands little or no effort; while perceived usefulness is the degree to which a user believes that using new information system would enhance task performance (Davis, 1989). The study used the Technology Acceptance Model (TAM) or an information technology 
theory as its framework because it describes how differences in expectations in terms of usefulness, ease of use and perceived credibility may influence taxpayers' decision on the usage of the online tax filing and payment facility of the Bureau of Internal Revenue.

\section{Conceptual Framework}

The conceptual framework of the study was based on the assumption that BIR online tax processes implementation and the degree of online tax processes capability of selected taxpayers in Mandurriao, Iloilo City are influenced by the independent variables of the study which the profile of the respondents consisting of sex, age, highest educational attainment, business industry and years in business. Also, the dependent variables of the study such as the level of online tax processes implementation perceived among respondents in terms of usefulness, ease of use and credibility conceptualized to be associated with the degree of online tax processes capability of selected taxpayers in terms of awareness and technical knowledge. While the arrow that connects between the level of online tax processes implementation and degree of online tax capability of selected taxpayers establishes the relationship between these two variables. The independent variable connected with a line to the dependent variables is assumed to effect a variation on the level of online tax processes implementation of BIR Iloilo City and capability of the selected taxpayers in Mandurriao, Iloilo City. It is conceptualized that the level of online tax processes implementation and degree of taxpayer's capability may differ considering their personal and business profiles. It is theorized that if the level of implementation is high, the degree of capability will also be high.

\section{Independent Variable}

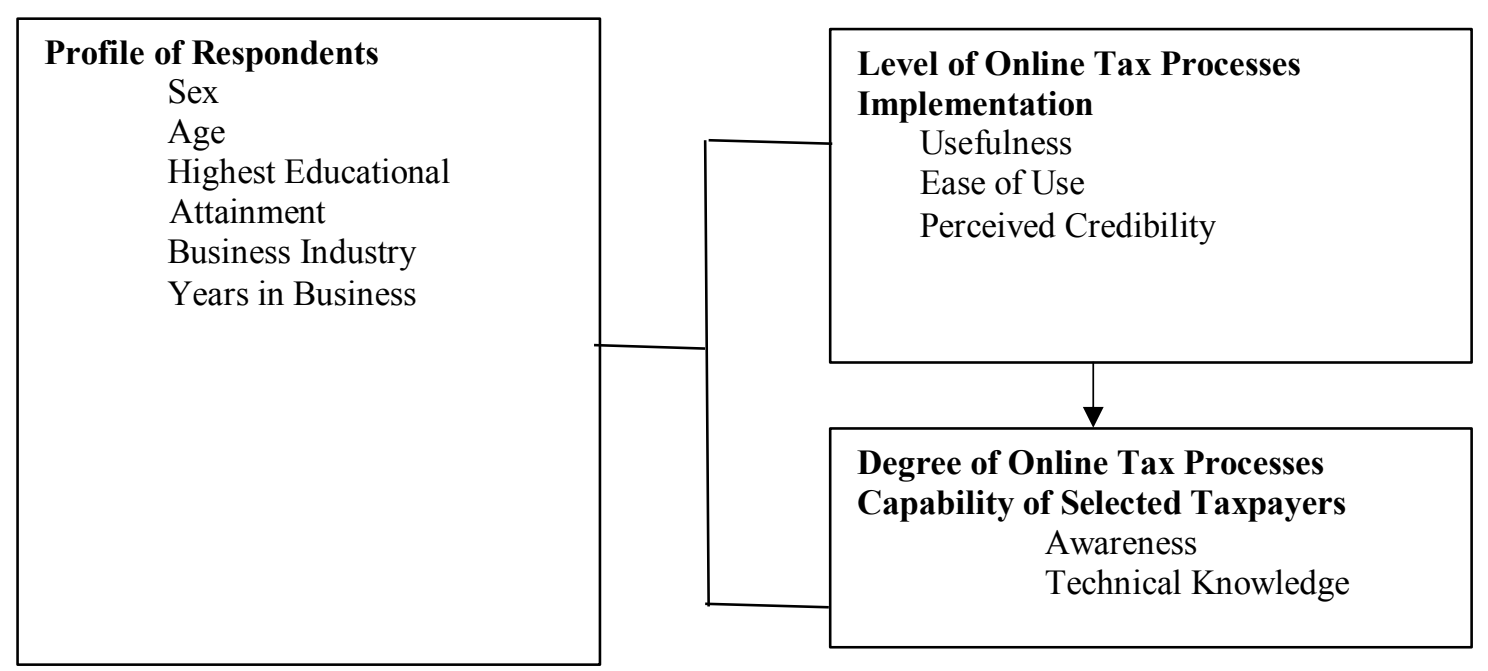

Figure 1. Schematic diagram showing the variables of the study.

\section{Literature Review}

Electronic tax filing and payment system. Properly developed, effective taxation systems are crucial for a well-functioning society. A good tax system should ensure that taxes are proportionate and certain (not arbitrary) and that the method of paying taxes is convenient to taxpayers. This includes offering taxpayers electronic systems for filing and paying taxes, merging taxes with the same tax base, allowing for selfassessment and having clear and efficient processes for refunding VAT cash refunds and undergoing tax audits. Electronic tax filing or e-filing is a process where tax documents or tax returns are submitted through the internet, usually without the need to submit any paper return.

The e-filing system encompasses the use of internet technology for a wide range of tax administration and compliance purposes. In the article entitled "Paying Taxes 2018", World Bank Group (2018), an electronic system for filing and paying taxes if implemented well and used by most taxpayers, benefits both tax authorities and firms. For tax authorities, electronic filing lightens the workload and reduces operational costs - such as the costs of processing, storing and handling tax returns. At the same time, it increases tax compliance and saves time. For taxpayers, electronic filing saves time by reducing calculation errors on tax returns and making it easier to prepare, file and pay taxes. For example, the cost of paper filing and reporting for personal income tax in the US (including the cost of filling numerous reporting forms and tax returns) 
can potentially reach up to $1.2 \%$ of GDP for the US. The ability to file and pay taxes electronically has a positive impact on firms in several economies in Latin America and the Caribbean.

In Uruguay, for example, the government adopted the Financial Inclusion Act on May 9, 2014, which included the compulsory electronic payment of national taxes in an effort to gradually increase both the economy's level of digitalization and the use of banking services. Most taxpayers were filing and paying their taxes online by early 2016, when the government added new features to the online platform. China began its tax modernization program - which involved redefining tax shares between the various tax authorities and transitioning from turnover taxes to value added taxes - in the early 1990s. Since then, China has implemented numerous improvements to its tax system, including the introduction of a taxpayer services hotline in 2005, the formation of a specialized Taxpayer Services Department and online filing and payment for the major taxes in 2008, and a campaign to improve cooperation between the State Taxation Administration and local tax bureaus, provide electronic notices to taxpayers and reduce the number of tax filings for certain taxpayers in 2013. Many tax administrations tackle such issues by updating their online systems continually.

Electronic tax filing system, an e-government application that is being utilized all over the world. Electronic filing (e-filing) is an application of the internet and networking technologies to digitally enable taxpayers and their Accountants or representatives to prepare and electronically file their tax returns. Effective implementation of the system is significant to the tax compliance of taxpayers. According to Leliya and Afiyah (2016) in their study entitled "The Effectiveness of Online Regional Tax Payment System in Increasing the Local Revenue of Cirebon City", revealed that in line with the rapid development of science and technology, the implementation of an online tax system is designed to facilitate the public in accessing information and provide ease in tax payment.

Online tax payments contribute to increased local revenue, for the online system in the payment of local taxes provides convenience for taxpayers in tax services, making the tax administration process more effective and keeping confidentiality of tax documents. Another study proved that proper implementation of the system has a great impact on tax compliance. Tarmidi et al, (2017) showed in their study entitled "Tax Compliance: Impact of Implementation Online Tax Application" that proper implementation of the online tax application and awareness of the taxpayers has a significant effect on tax compliance. Electronic filing is beneficial because taxpayers can avail of a paperless tax filing experience in which they can save time and long queues as compared to manual filing.

This paper shows the importance of the e-filing system for taxpayers and tax administration and the advantages and disadvantages of this system. Reasons for the implementation of this system are numerous, because of the facilities it offers: transparency system, saving time, avoiding the tax evasion, simplification of procedure, equal treatment of taxpayers by tax authorities. Studies have shown that people tend to use online tax filing as it is more convenient and quicker than traditional paper tax filing. They concluded that improving aspects of the e-filing system that would enhance taxpayers' perceived ease of use, usefulness and reduce the riskiness of the system are essential to increase adoption of the e-filing system. Success of the implementation of electronic tax filing and payment systems depend on how the user accepts it. Electronic filing and payment systems improve the efficiency of the tax assessment method by increasing tax collection and reducing computation errors. income tax, value-added tax (VAT), payroll taxes and excise taxes] are most likely to use e-filing.

Taxation knowledge is necessary to increase public awareness especially in areas concerning taxation laws, the role of tax in national development, and especially to explain how and where the money collected is spent by the government (Mohd, 2010). Attitude towards tax compliance can be improved through the enhancement of taxation knowledge. A positive tax attitude helps reduce negative perceptions about tax thus increasing taxpayers' tax compliance. In addition, a knowledge-equipped taxpayer is particularly favorable for the government because they avoid many of the mistakes taxpayers make in manual filings, and they help to prevent tax evasion by data matching (Manly et al, 2005). For taxpayers using the manual method, lack of facilitating conditions such as access to computer and internet resources was the most significant barrier to e-Filing usage whilst taxpayers using the electronic method reported perceived usefulness as the primary determinant in their decision to use e-Filing (Jankeeparsad, 2014).

The low awareness of a taxpayer is suspected to be caused by the minimum knowledge and understanding of tax regulations (Alabede et al, 2011). Nurlis (2015) describes some form of consciousness of paying taxes that encourages taxpayers to pay taxes. Knowing this, a taxpayer would pay taxes because they are not disadvantaged when tax collection is done. With increasing use of the online tax filing system over the years, there are still businesses who do not submit online due to lack of awareness of the actual requirements for online filing. In the paper of Geetha and Sekar (2012) entitled "Awareness and satisfaction level of E- 
Filing individual tax payers, it mainly focuses on assessing awareness and satisfaction level of tax payers about e-filing of income tax returns. This study reveals that the existing users are satisfied with the e-filing facilities but most of the individual tax payers are not aware of the e-filing and e-payment procedures. So sufficient steps are required to create more awareness in the minds of taxpayers regarding e-filing of income tax. Therefore, the authors suggested that adequate steps to create more awareness in the minds of taxpayers regarding e-filing of income tax must be provided. Some countries have been working hard to achieve their goal of establishing a better online tax system.

\section{Research Methods}

This study employed descriptive-correlational research design since it provides essential knowledge about the concepts and the relationship of variables (Creswell (2012). The participants of the study were 155 taxpayers from a population of 172 business registrants (mixed of sole proprietorship, partnership and corporation) in Mandurriao, Iloilo City who were included in the Taxpayer's Account Management Program (TAMP) of the BIR.

The research applied Likert Scale to measure perceptions or opinions of the respondents (Saul McLeod, 2018; Edmondson, 2005 and McLeod, 2014). Part I dealt with the profile of the respondents. Part II assessed the level of online tax processes implementation of BIR Iloilo City in terms of online tax filing and payment services. Part III measured the degree of online tax processes capability of selected taxpayers in Mandurriao, Iloilo City. The responses were gathered, checked and tabulated in Microsoft Excel in preparation for data analysis. It was processed using the Statistical Package for Social Science Software (SPSS), scored and given corresponding verbal interpretations. Descriptive and inferential statistics were used using the Statistical Package for Social Science Software (SPSS). The research used frequency count, percentage, t-test and f-test as descriptive statistical tools and to describe the relationship between variables in a sample or population (Satake, 2015). The Pearson Product Correlation coefficient (Pearson-r) was used to determine the relationship between the level of online tax processes implementation and the degree of online tax processes capability of taxpayers (Higgins, 2005).

\section{Results and Discussion}

\section{Level of Online Tax Processes Implementation}

Presented in Table 1 is the level of online tax processes implementation of the Bureau of Internal Revenue (BIR) Iloilo City as a whole as perceived by the respondents. The level of online tax processes implementation had an overall mean of 3.49 was described high. The highest mean of 3.55 was on the indicator, "Perceived Credibility" followed by the mean of 3.52 on the indicator "Ease of Use". The lowest grand mean of 3.41 was on the indicator, "Usefulness". This implies the level of online tax processes implementation as a whole is high, which means that the statements regularly manifested to the respondents to a certain degree. The result supports the study of Azmi and Bee (2010) who concluded that improving aspects of the e-filing system that would enhance taxpayers' perceived ease of use, usefulness and reduce the riskiness of the system are essential to increase adoption of the e-filing system.

Table 1. Level of online tax processes implementation of BIR Iloilo City.

\begin{tabular}{lcc}
\hline \multicolumn{1}{c}{ Component } & Grand Mean & Verbal Interpretation \\
\hline Usefulness & 3.41 & High \\
Ease of Use & 3.52 & High \\
Perceived Credibility & 3.55 & High \\
Grand Mean & 3.49 & High \\
\hline
\end{tabular}

Usefulness. The grand mean level of online tax processes implementation of BIR Iloilo City in terms of usefulness as perceived by the respondents is presented in Table 2 has 3.41 mean. The level of online tax processes implementation of BIR Iloilo City in terms of usefulness was high. BIR electronic tax filing and payment system help speed up the tax filing and payment process. The implementation of online tax processes by the Bureau of Internal Revenue (BIR) is primarily to provide Philippine taxpayers with top quality and convenient service through faster processing and immediate confirmation of filing tax returns and payment of taxes due. The result indicated faster processing of filing and payment tax obligations using the online tax system implies that taxpayers are well-informed about the online system would help ease the hassle through storing and communicating information in electronic form rather than written. The online tax filing system may be stable to handle the high traffic during peak times. Likewise, Leliya and Afiyah (2016) opined that in line with the rapid development of science and technology, the implementation of an online tax system is designed to facilitate the public in accessing information and 
provide ease in tax payment.

Table 2. Level of online tax processes implementation of BIR Iloilo City in terms of usefulness.

\begin{tabular}{lcc}
\hline \multicolumn{1}{c}{ Statement } & Mean & $\begin{array}{c}\text { Verbal } \\
\text { Interpretation }\end{array}$ \\
\hline $\begin{array}{l}\text { 1. The BIR electronic tax filing and payment } \\
\text { and payment process. }\end{array}$ & High \\
$\begin{array}{l}\text { 2. The use of the BIR electronic tax filing and payment system is an additional burden } \\
\text { because it requires me additional cost for the use of internet. }\end{array}$ & 2.60 & Average \\
$\begin{array}{l}\text { 3. The BIR electronic tax filing and payment system improves my understanding } \\
\text { in preparing tax returns. }\end{array}$ & 3.55 & High \\
$\begin{array}{l}\text { 4. The online tax system is not helpful because I still need to go to BIR to report } \\
\text { my tax payment when system is inaccessible. }\end{array}$ & Low \\
$\begin{array}{l}\text { 5. The BIR electronic tax filing and payment system reduces my errors in filing tax } \\
\text { returns. }\end{array}$ & High \\
$\begin{array}{l}\text { 6. The BIR online tax system does not improve my understanding of how to } \\
\text { prepare my income tax return as it provides automatic preparation. }\end{array}$ & Low \\
$\begin{array}{l}\text { 7. The BIR electronic tax filing and payment system provides easy calculation of my tax } \\
\text { liability. }\end{array}$ & 3.60 & High \\
$\begin{array}{l}\text { 8. The use of BIR electronic tax filing and payment system helps me in carrying out my } \\
\text { tax obligations. }\end{array}$ & 3.79 & High \\
$\begin{array}{l}\text { 9. The BIR electronic tax filing and payment system is environment friendly as it } \\
\text { minimizes my paper usage. }\end{array}$ & 3.89 & High \\
$\begin{array}{l}\text { 10. With the use of the BIR electronic tax filing and payment system, I can report } \\
\text { taxes anytime and anywhere. }\end{array}$ & 3.90 & High \\
\hline
\end{tabular}

Ease of use. The level of online tax processes implementation of BIR Iloilo City in terms of ease of use presented in Table 3 had a grand mean of 3.52. The online tax system makes an effective impact on the economy toward improving the level of income generation and tax compliance by the taxpayers. It is convenient, time saving, and cost effective from both the administrators and taxpayers (Azmi and Bee, 2010). The electronic tax filing and payment system is effortless, and convenient for taxpayers to file returns anytime, anywhere and easier for the BIR to detect errors. Ease of use of the system of BIR 24/7 including holidays. The availability of the system $24 / 7$ online tax filing and payment system signifies taxpayers can file and pay taxes anytime, anywhere provided a computer has internet connection, otherwise taxpayers resort to manual process. Through the system, it may improve positive attitude and commitment in paying taxes, would elicit voluntary compliance by willingly reporting and filing tax returns and tax obligations.

Table 3. Level of online tax processes implementation of BIR Iloilo City in terms of ease of use.

\begin{tabular}{|c|c|c|}
\hline Statement & Mean & Verbal Interpretation \\
\hline $\begin{array}{l}\text { 1. The BIR website provides me with simple and detailed instructions } \\
\text { on the use of electronic tax filing and payment system. }\end{array}$ & 3.70 & High \\
\hline $\begin{array}{l}\text { 2. The BIR online tax system has no manual instruction to guide me on } \\
\text { how to use the system }\end{array}$ & 3.45 & High \\
\hline $\begin{array}{l}\text { 3. I find the BIR online tax system not user friendly as it provides a } \\
\text { complex process in preparing my tax returns. }\end{array}$ & 2.65 & Average \\
\hline $\begin{array}{l}\text { 4. I can use the electronic tax filing and payment system of BIR } 24 / 7 \\
\text { including holidays. }\end{array}$ & 3.97 & High \\
\hline $\begin{array}{l}\text { 5. Using electronic tax filing and payment systems provides me } \\
\text { convenience to file and pay taxes anytime and anywhere. }\end{array}$ & 3.79 & High \\
\hline $\begin{array}{l}\text { 6. I prefer to file and pay my tax obligation manually because the BIR } \\
\text { website is sometimes not accessible. }\end{array}$ & 3.72 & High \\
\hline $\begin{array}{l}\text { 7. The electronic tax filing and payment system requires me to do the } \\
\text { fewest steps possible to accomplish my tax return filing. }\end{array}$ & 3.74 & High \\
\hline $\begin{array}{l}\text { 8. I refuse to use the BIR online tax system because it offers no online } \\
\text { assistance. }\end{array}$ & 3.07 & Average \\
\hline $\begin{array}{l}\text { 9. The BIR online tax system has a slow response or acknowledgment } \\
\text { in every transaction I made. }\end{array}$ & 3.26 & Average \\
\hline $\begin{array}{l}\text { 10. The BIR online tax filing and payment system assists me to pay my } \\
\text { tax liability through the internet banking facilities. }\end{array}$ & 3.81 & High \\
\hline Grand Mean & 3.52 & High \\
\hline
\end{tabular}


Perceived credibility. The ten (10) statements on the level of online tax processes implementation of BIR Iloilo City in terms of perceived credibility had means which ranged from 2.90 to 3.92. The indicative result of high mean in the statement on minimization of errors encountered in online tax processes implies that the efficiency of respondents in filing and payment of their tax obligation is high. Contrariwise, the average result on the statement encountered data loss when computer crashes or losing Internet signifies that dealing with technology problems signaled a problem of servers as being the weakness of online tax processes. As stated by Harold (2011), computer-generated returns, transmitted electronically, generally are easier to process than paper returns; since the information on the forms doesn't have to be keyed in, number by number, by IRS staff into the Service's computers hence there is less chance of errors. According to Chang et al (2005), a credible website needs to safeguard personal information from unauthorized access or disclosure, accidental loss and alteration or destruction.

Table 4. Level of online tax processes implementation of BIR Iloilo City in terms of perceived credibility.

\begin{tabular}{|c|c|c|}
\hline Statement & Mean & Verbal Interpretation \\
\hline $\begin{array}{l}\text { 1. The electronic tax filing and payment system has security } \\
\text { features that secure all my transactions made. }\end{array}$ & 3.71 & High \\
\hline $\begin{array}{l}\text { 2. The electronic tax filing and payment system requires my login } \\
\text { authentication as user's validation. }\end{array}$ & 3.74 & High \\
\hline $\begin{array}{l}\text { 3. I find the BIR online tax system not credible as it accepts } \\
\text { simplified password access. }\end{array}$ & 3.10 & Average \\
\hline $\begin{array}{l}\text { 4. Electronic tax filing and payment system encourage me to } \\
\text { change user password regularly for security purposes. } \\
\text { 5. The electronic tax filing and pavment system protects my }\end{array}$ & 3.42 & High \\
\hline $\begin{array}{l}\text { 5. The electronic tax filing and payment system protects my } \\
\text { information because of the security features embedded in the } \\
\text { system. }\end{array}$ & 3.71 & High \\
\hline $\begin{array}{l}\text { 6. Filing and payment using an online tax system might } \\
\text { provide an opening for the hackers to steal my identity. }\end{array}$ & 3.29 & Average \\
\hline $\begin{array}{l}\text { 7. Electronic tax filing and payment system has adequate } \\
\text { safety standards to protect my data. }\end{array}$ & 3.82 & High \\
\hline $\begin{array}{l}\text { 8. The system displays "information error" when I encounter } \\
\text { erroneous transactions. }\end{array}$ & 3.87 & High \\
\hline $\begin{array}{l}\text { 9. My errors are minimized when using the system because } \\
\text { supplied information is validated before submission. }\end{array}$ & 3.92 & High \\
\hline $\begin{array}{l}\text { 10. I encountered loss of data when my computer crashes or lost } \\
\text { internet access. }\end{array}$ & 2.90 & Average \\
\hline Grand Mean & 3.55 & High \\
\hline
\end{tabular}

Degree of Online Tax Processes Capability of Taxpayers

The degree of online tax processes capability of taxpayers of BIR Iloilo City as a whole had an overall mean of 3.34 as presented in Table 5. The two indicators on degree of online tax processes capability as a whole had grand means of 3.29 and 3.40 both with verbal interpretation of high, which means that statements are regularly manifested to a certain degree. The highest grand mean of 3.40 was on indicator, "Technical Knowledge". The lowest grand mean of 3.29 was on indicator, "Awareness."

Table 5. Degree of online tax processes capability of taxpayers of BIR Iloilo City as a whole.

\begin{tabular}{lcc}
\hline \multicolumn{1}{c}{ Indicator } & Mean & $\begin{array}{c}\text { Verbal } \\
\text { Interpretation }\end{array}$ \\
\hline Awareness & 3.29 & High \\
Technical Knowledge & 3.40 & High \\
$\quad$ Grand Mean & 3.34 & High \\
\hline
\end{tabular}

Awareness. The result of the study discloses that the grand mean on the degree of online tax processes capability of taxpayers of BIR Iloilo City in terms of awareness as perceived by the respondents was 3.29 as presented in Table 6 . This grand mean implied that the respondents perceived the degree of online tax processes capability of taxpayers of BIR Iloilo City in terms of awareness as high. However, computer anxiety is most likely to be an issue among the illiterate, semi-illiterate and the elderly taxpayers which 
may reduce their confidence around computer technologies such as the online tax filing system. Table 6. Degree of online tax processes capability of taxpayers of BIR Iloilo City in terms of awareness.

\begin{tabular}{|c|c|c|c|}
\hline & Statement & Mean & Verbal Interpretation \\
\hline 1. & $\begin{array}{l}\text { I can find the online tax filing procedures by visiting the BIR } \\
\text { website. }\end{array}$ & 4.15 & High \\
\hline 2. & $\begin{array}{l}\text { The online tax filing and payment facility provides me with a } \\
\text { fast and convenient manner in transacting with BIR } \\
\text { transactions. }\end{array}$ & 3.77 & High \\
\hline 3. & $\begin{array}{l}\text { I spend more time filing my tax returns using the online tax } \\
\text { filing facility because of the complex procedures. }\end{array}$ & 2.51 & Low \\
\hline 4. & $\begin{array}{l}\text { The online tax filing and payment facility can help me to pay } \\
\text { taxes online through the convenience of online banking service } \\
\text { via debit from the enrolled bank account. }\end{array}$ & 3.75 & High \\
\hline 5. & $\begin{array}{l}\text { I feel insecure in using the online tax payment facility because } \\
\text { I might encounter error in payment due to unsuccessful } \\
\text { attempts caused of the slow connection. }\end{array}$ & 2.46 & Low \\
\hline 6. & $\begin{array}{l}\text { I feel nervous to use the online tax filing because there was no } \\
\text { online assistance to guide me on the BIR website. }\end{array}$ & 2.39 & Low \\
\hline 7. & $\begin{array}{l}\text { I can avail the online tax filing and payment services } 24 / 7 \\
\text { including holidays, anytime and anywhere. }\end{array}$ & 3.92 & High \\
\hline 8. & $\begin{array}{l}\text { I prefer to file and pay taxes manually because I don't have the } \\
\text { knowledge to e-file my tax returns. }\end{array}$ & 3.39 & Average \\
\hline & $\begin{array}{l}\text { I find the system not environmentally friendly because I still } \\
\text { need to print my e-filed tax returns for I can no longer retrieved } \\
\text { once I submitted the data. }\end{array}$ & 2.68 & Average \\
\hline & $\begin{array}{l}\text { I can pay my taxes online using GCash, PayMaya and other } \\
\text { alternative e-Payment channels. }\end{array}$ & 3.90 & High \\
\hline & Grand Mean & 3.29 & High \\
\hline
\end{tabular}

Technical knowledge. Presented on Table 7 is the grand mean of 3.41 on the degree of online tax processes capability of taxpayers of BIR Iloilo City in terms of technical knowledge. The grand mean implies that the respondents perceived the degree of online tax processes capability of taxpayers of BIR Iloilo City in terms of technical knowledge as high. The highest mean of 3.88 is that it helps to file and pay my tax obligations. The lowest mean was 2.61 . The average system is not user friendly for someone like me who is not computer savvy."

Table 7. Degree of online tax processes capability of taxpayers of BIR Iloilo City in terms of technical knowledge.

\begin{tabular}{|c|c|c|c|}
\hline & Statement & Mean & Verbal Interpretation \\
\hline 1. & $\begin{array}{l}\text { I am computer savvy and I can file my income tax return online with } \\
\text { technical ease. }\end{array}$ & 3.83 & High \\
\hline 2. & $\begin{array}{l}\text { I am able to fill up taxpayer's information required in the online tax } \\
\text { filing and payment system. }\end{array}$ & 3.83 & High \\
\hline 3. & $\begin{array}{l}\text { I find the system not user friendly for someone like me who is not a } \\
\text { computer savvy. }\end{array}$ & 2.61 & Average \\
\hline 4. & $\begin{array}{l}\text { I can file and pay my taxes online even if there is no one to show me } \\
\text { how to do it. }\end{array}$ & 3.59 & High \\
\hline 5. & $\begin{array}{l}\text { I find the system difficult to use because I don't know how to deal } \\
\text { with technology problems. }\end{array}$ & 2.93 & Average \\
\hline 6. & $\begin{array}{l}\text { I can deal with technical issues encountered in terms of computer } \\
\text { crashes or loss of internet connection when using online tax filing } \\
\text { and payment facilities. }\end{array}$ & 3.58 & High \\
\hline 7. & $\begin{array}{l}\text { It is hard for me to file taxes online because I don't know how to } \\
\text { access the internet alone. }\end{array}$ & 2.94 & Average \\
\hline 8. & $\begin{array}{l}\text { I encountered no issues in terms of computer usage in filing and } \\
\text { paying taxes using the online system facility. }\end{array}$ & 3.15 & Average \\
\hline 9. & I find it easier to file taxes manually than do it online. & 3.63 & High \\
\hline \multicolumn{4}{|c|}{$\begin{array}{l}\text { 10. I find computer and internet connection helpful to file and pay my } \\
\text { tax obligations. }\end{array}$} \\
\hline & Grand Mean & 3.40 & High \\
\hline
\end{tabular}


Differences on the Level of Online Tax Processes Implementation

The respondents' profile is presented in Table 8 to aid the analysis of the differences in the level of online tax processes implementation of the BIR Iloilo City in terms of selected variables such as sex, age, highest educational attainment, type of business industry and years in business.

Table 8. Profile of the respondents.

\begin{tabular}{llcc}
\hline & Personal Profile & Frequency & Percentage (\%) \\
\hline Sex & Male & 98 & 63.20 \\
& Female & 57 & 36.80 \\
Total & 155 & 100.00 \\
& 18 to 37 years old & 41 & 26.50 \\
& 38 to 57 years old & 94 & 60.60 \\
& 58 years old and above & 20 & 12.90 \\
& Total & 155 & 100.00 \\
Highest & & \\
& Educational Attainment & 11 & 7.10 \\
& High School Graduate & 123 & 79.40 \\
& College Graduate & 21 & 13.50 \\
& Others & 155 & 100.00 \\
Total & 25 & \\
Type of Industry & 27 & 16.10 \\
& Sale of Goods & 103 & 17.40 \\
Sale of Services & & 66.50 \\
Mix (Both Sale of Goods and & 155 & \\
Services) & & 100.00 \\
Total & 48 & 23.90 \\
Years in Business & 127 & 34.80 \\
New -5 years & 22 & 41.30 \\
6-10 years & 155 & 100.00 \\
\hline 11 years and above & &
\end{tabular}

Reflected in Table 9 shows the differences in the level of online tax processes implementation of the BIR Iloilo City using the significant values and their corresponding result of probability.

Results highlighted no significant differences found in the level of online tax processes implementation of the BIR Iloilo City when grouped according to sex, age, type of business industry and years in business. Therefore, the result of the null hypothesis stating that there are no significant differences in the level of online tax processes implementation of the BIR Iloilo City considering the variables is accepted since the significant values were higher than $0.05 \%$ alpha. This implied variation is not evident on the level of online tax processes implementation of the BIR Iloilo City as to sex age, type of business industry and years in business. However as to educational attainment difference on the level of online tax processes implementation was manifested. Therefore, the null hypothesis stating that there are no significant differences in the level of online tax processes implementation of the BIR Iloilo City in terms of highest educational attainment is rejected.

Table 9. Differences in the perception of the respondents on the level of online tax processes implementation of the BIR Iloilo City as a whole and when grouped according to selected variables.

\begin{tabular}{lcl}
\hline \multicolumn{1}{c}{ Variable } & Significant Value & Probability \\
\hline Sex & 0.245 & n.s. \\
Age & 0.603 & n.s. \\
Educational Attainment & 0.002 & s. \\
Type of Business Industry & 0.425 & n.s. \\
Years in Business & 0.097 & n.s. \\
\hline
\end{tabular}


Differences in the Degree of Online Tax Processes Capability of Taxpayers

The differences in the degree of online tax processes capability of taxpayers of BIR Iloilo City are shown in Table 10 using the significant values of $0.05 \%$ and corresponding result of probability. Findings disclosed no significant differences found in the degree of online tax processes capability of taxpayers of BIR Iloilo City when they were grouped according to sex, age, educational attainment, type of business industry and years in business. Therefore, the null hypothesis stating that there are no significant differences in the degree of online tax processes capability of taxpayers of BIR Iloilo City when they are grouped according to sex, age, educational attainment, type of business industry and years in business is accepted. Mandurriao, being part of the highly urbanized Iloilo City, has taxpayers who are more likely to adopt the online tax processes of BIR as it provides convenience, security and ease in filing and payment of taxes. Large businesses, located in urban areas, operating in capital-intensive sectors, and paying multiple taxes [e.g. income tax, value-added tax (VAT), payroll taxes and excise taxes] will likely use e-filing. As Coolidge and Yllmaz (2014) in addition the availability of reliable Internet access and electricity, capability in computer usage, awareness of e-filing and knowledge about the process is important for taxpayers' efiling decisions.

Table 10. Differences in the degree of online tax processes capability of taxpayers of BIR Iloilo City as a whole and when grouped according to selected variables.

\begin{tabular}{lcr}
\hline \multicolumn{1}{c}{ Variable } & Significant Value & Probability \\
\hline Sex & 0.068 & n.s. \\
Age & 0.777 & n.s. \\
Educational Attainment & 0.106 & n.s. \\
Type of Business Industry & 0.796 & n.s. \\
Years in Business & 1.000 & n.s. \\
\hline
\end{tabular}

\section{Relationship between Level of Online Tax Processes Implementation and Degree of Online Tax}

Processes Capability

Data in Table 11 reflects that there was a significant relationship between the level of online tax processes implementation of BIR Iloilo City and their perceptions on the degree of online tax processes capability of taxpayers. The computed Pearson r-ratio value of 0.626 had a p-value of 0.000 which was less than 0.05 alpha. Therefore, the null hypothesis stating that there is no significant relationship between the level of online tax processes implementation of BIR Iloilo City and the degree of online tax processes capability of taxpayers is rejected.

The online tax processes of BIR Iloilo City in filing and payment of taxes electronically is quite effective when level of implementation is high, degree of capability is also high and vise versa. This result implies that the respondent's perception of the level of online tax processes implementation of BIR Iloilo City was associated with their perception of the degree of online tax processes capability of taxpayers. The result implied the success of implementation of online tax processes of BIR is dependent on the capability of selected taxpayers in Mandurriao, Iloilo City. By using the electronic tax filing and payment system, taxpayers may directly encode and submit their taxes online with the use of the internet through the BIR website (Rafal, 2011). Also, Alla (2014) asserted the reasons for the implementation of the online system: transparency system, saving time, avoiding tax evasion, simplification of procedures, and equal treatment of taxpayers by tax authorities.

Table11.Relationship between the level of online tax processes implementation of BIR Iloilo City and the degree of online tax processes capability of taxpayers.

\begin{tabular}{lccccc}
\hline Value & $\mathrm{N}$ & Mean & $\begin{array}{l}\text { Pearson r- } \\
\text { ratio }\end{array}$ & p-vlaue & Probability \\
\hline $\begin{array}{l}\text { Level of Online Tax Processes } \\
\text { Implementation }\end{array}$ & 155 & 3.4910 & & & \\
& 155 & 3.3445 & & 0.626 & s. \\
$\begin{array}{l}\text { Degree of Online Tax } \\
\text { Processes Capability }\end{array}$ & & & & & \\
\hline
\end{tabular}




\section{Conclusions}

1. The taxpayers consistently manifested adaptability to modern technology whereby they knowledgeably perform online tax processes.

2. The level of online processes implementation varied except on the highest educational attainment of the respondents.

3. The selected profile of the respondents has negligible bearing on their capability to perform online tax processes.

4. The perception of the respondents on the level of implementation on online tax processes was significantly associated with the degree of capability to perform online tax processes.

\section{Implications}

Since the system implemented is new and the majority have limited knowledge and experience as well as inconveniences on e-tax filing, a reach out program may address the need. It can be in bigger municipalities, accessible to the paying public. It will defeat the purpose and waste of money if limited clients will be able to utilize the system. The Bureau may prioritize that at least there are five (5) personnel who are conversant with the system in each municipality.

Likewise weak connection is a common problem that causes dissatisfaction of clientele, these could be prioritized among other programs to limit e-traffic loads and save time, efforts and money especially those in remote areas.

To facilitate e-tax filing literacy, the BIR may designate personnel among municipalities to train the representative members of the community to serve as trainers on scheduled basis and at the same time promote tax collection. One time training will not be sufficient for a person to get all the knowledge needed.

\section{References}

Alabede J, Zainol, Z and Idris K. (2011). Individual Taxpayers' Attitude And Compliance Behaviour In Nigeria: The Moderating Role Of Financial Condition And Risk Preference. College of Business Universiti Utara Malaysia, Sintok, Kedah State-Malaysia. Journal of Accounting and Taxation Vol. 3(5), pp. 91-104, September 2011

Ayesha S and Mynavathi L (2018). Awareness And Satisfaction Level Of Tax Payers Towards E-filing Of Income Tax Returns. International Research Journal of Commerce Arts and Science. Volume 9. Issue 1.ISSN $2319-9202$.

Creswell, J. W. (2012). Educational Research: Planning, Conducting, and Evaluating Quantitative and Qualitative Research. 4th Edition. Boston, MA: Pearson Education, Inc.

Gayathri P, Jayakumar K. (2016). A Study on Tax Payer's Perception Towards E-Filing of Income Tax Returns. International Journal of Trend in Research and Development. Pages 32-38.

Geetha R. and Sekar M. (2012). E-Filing of Income Tax: Awareness and Satisfaction level of individual Tax payers in Coimbatore City, India. School of Business Management, Rathnavel Subramaniam College of Arts and Science Sulur, Coimbatore, India. Research Journal of

Leliya L. and Afiyah F. 2016. The Effectiveness of Online Regional Tax Payment System in Increasing the Local Revenue of Cirebon City. Volume 4. No. 2.

Management Sciences. Vol. 1(4), 6-11, November (2012). ISSN 2319-1171.

Matharu S, Haryani S, Motwani B, (2015) Behavioral Intention of Taxpayers towards Online Tax Filing in India: An Empirical Investigation. Journal of Business and Financial Affairs. Volume 4. January 2015.

Muita, E. W. (2011). Factors That Influence Adoption And Use Of E-Filing System Of Kenya Revenue Authority Among The Large Taxpayers.

Nurlis, IK (2015). The Effect of Taxpayer Awareness, Knowledge, Tax Penalties and Tax Authorities Services on the Tax Compliance. Research Journal of Finance and Accounting. Vol.6, No.2, 2015.

Roxas, Gregorio S. Valencia, Edwin G. (2013). Income Taxation Principle and Laws with Accounting Application. Philippines: Valencia Educational Supply.

Unpublished MBA Project submitted to the JKUAT Nairobi Central Business District Campus. 